\title{
Levels of Biologically Active Compounds and some Essential Metal in Parts of African Oil Bean Tree (Pentaclethra macrophylla)
}

\section{*1OGBONNA, PC; ${ }^{2}$ PRINCEWILL-OGBONNA, IL; ${ }^{1}$ NZEGBULE, EC; ${ }^{1}$ MPAMAH IC; ${ }^{1}$ NWACHUKWU, NG}

\author{
${ }^{I}$ Department of Environmental Management and Toxicology, Michael Okpara University of Agriculture, Umudike, PMB 7267 Umuahia, \\ Abia State, Nigeria \\ ${ }^{2}$ Department of Food Science and Technology, Michael Okpara University of Agriculture, Umudike, PMB 7267 Umuahia, Abia State, \\ Nigeria \\ *Corresponding Author Email: ogbonna_princewill@yahoo.com; +2348063402809
}

\begin{abstract}
The study assessed the phytochemical and mineral content in leaves, root and bark of Pentaclethra macrophylla in Amumara Mbaise, Imo State. The qualitative analysis show that the root extract had the highest tannin $(++)$, flavonoid (+++), alkaloid (+++), and saponin (+++) with high degree of precipitation while phenol (+++) and phytate $(+++)$ occurred in the leaves extract. Quantitatively, the highest significant $(\mathrm{P}<0.05)$ content of tannin $(1.42 \pm 0.00 \%)$, flavonoid $(3.75 \pm 0.35 \%$, alkaloid $(1.30 \pm 0.14 \%)$, and saponin $(3.40 \pm 0.00 \%)$ were obtained in the root while the highest significant $(\mathrm{P}<0.05)$ content of the minerals: $\mathrm{Mg}(158.00 \pm 0.00 \mathrm{mg} / 100 \mathrm{~g}), \mathrm{Fe}(16.50 \pm 0.00 \mathrm{mg} / 100 \mathrm{~g}), \mathrm{Na}(165.00 \pm 0.00$ $\mathrm{mg} / 100 \mathrm{~g})$, and $\mathrm{Ca}(224.15 \pm 0.00 \mathrm{mg} / 100 \mathrm{~g})$ were observed in the leaves. The results indicate that $P$. macrophylla is a promising tree species that can improve the health of man.
\end{abstract}

\section{DOI: https://dx.doi.org/10.4314/jasem.v22i9.18}

Copyright: Copyright (C) 2018 Ogbonna et al. This is an open access article distributed under the Creative Commons Attribution License (CCL), which permits unrestricted use, distribution, and reproduction in any medium, provided the original work is properly cited.

Dates: Received: 17 July 2018; Revised: 22 August: 2018; Accepted: 30 August 2018

Key words: Mineral, phytochemical, leaves, roots

Medicinal plants are plants with active ingredients and rich in curative properties that can be used in manufacturing of drugs. These plants are used alone or combined with other plants because of their bioactive compounds (i.e. phytochemicals) such as saponins, flavonoids, tannins, alkaloids, phenols among others. For instance, tannins and saponins display cytotoxic effects and growth inhibition, making it suitable as tumor inhibiting agents (Asl and Hossein, 2008). Flavonoids is used as flavoring agents in food, drink and drug industries (You et al., 1993. Macro elements (minerals) including phosphorus $(\mathrm{P})$, potassium $(\mathrm{K})$, calcium $(\mathrm{Ca})$, sodium $(\mathrm{Na})$, magnesium $(\mathrm{Mg})$, sulphur (S) are involve in acid-base balance and cell metabolism (Smith, 1998).

The use of medicinal plants is common in the maintenance of health in developing countries (UNESCO, 1996). Consequently, the use of plant species, plant extracts or plant-derived pure chemicals to treat disease in Nigeria has become a therapeutic modality but one of the impediments in its acceptance by all is lack of established standard quality control measures. Thus, the assessment of phytochemical and elemental content of medicinal plants such as Pentaclethra macrophylla is very important since majority of people in developing country such as Nigeria relied heavily on medicinal plants due to its efficacy and low cost.

Pentaclethra macrophylla Benth; family: leguminosae (common name: African oil bean tree) is a major source of nutrition especially in south east Nigeria. The tree grows to a height of $32 \mathrm{~m}$ with bole up to 98 $\mathrm{cm}$ in diameter while the leaves is alternate and the seeds elliptical in outline, flattened, smooth, and purplish brown. Research work has been carried out on $P$. macrophylla including chemical evaluation and nutritional potential of the African oil bean seed (Osabor et al., 2017; Onyeleke et al., 2014; Allinor and Oze, 2011; Ogueke et al., 2010) and leaves (Osabor et al., 2017). However, extensive literature search show that no research has been carried out on the phytochemical and mineral content in leaves, root and bark of $P$. macrophylla. There is, therefore, paucity of literature on phytochemical and mineral content of $P$. macrophylla the world over. This study, therefore, is aimed to fill the gap in scientific knowledge by providing data on phytochemical and mineral content in leaves, root and bark of this promising plant species. 


\section{MATERIALS AND METHODS}

Study area: This study on phytochemical and mineral content in leaves, root, and bark of Pentaclethra macrophylla was carried out in Amumara Mbaise. Amaumara is one of the communities in Ezinihitte Mbaise local Government Area in Imo State located in the lowland tropical forest zone of Nigeria (Keay, 1959). It lies within latitudes $5^{\circ} 25^{\prime} \mathrm{N}$ and longitude $7^{\circ} 18^{\prime} \mathrm{E}$ and the day light is $12 \mathrm{~h} 22 \mathrm{~min} 25 \mathrm{sec}$. The hottest months are February and March, with mean annual temperature of $25^{\circ} \mathrm{C}$ and the soils is largely loamy in nature. Crops such as yam, cassava, maize, okra, coco yam among others are mainly grown by the farmers.

Experimental procedure: Fresh leaves, bark and root of Pentaclethra macrophylla were collected randomly using well cleaned secateurs from nine (9) different mature stands of African oil bean tree located in three different locations in Ubahi Amumara Community. The leaves were sampled from the different branches of each of the stands, and the bark were sampled at four cardinal points along the circumference from diameter at breast height of each of the stands while the roots samples were collected from the roots in four cardinal direction of each of the stands. Each of the samples (e.g. the leaves from different branches of the 9 mature stands of Pentaclethra macrophylla were bulked together and placed in large, well cleaned Abia State Environmental Protection Agency (ASEPA) poly bags, labeled well, covered properly, and taken to the laboratory for pre-treatment and analysis. Each of the samples were rinsed with distilled water to remove dust and pollen grain and air dried at room temperature until complete dryness (no change in weight). The dried samples were pulverized with an electric milling machine (Mortar Grinder RM 200) and stored in air tight plastic bottles for analysis.

Analysis of mineral content: The mineral content of the samples was processed following the dry ash extraction method (James, 1995). A known weight of each of the samples was burnt separately to ashes thereby removing all the organic materials leaving the inorganic ash. The resulting ash was dissolved in $5 \mathrm{ml}$ dilute $2 \mathrm{M} \mathrm{HCl}$ solution and diluted to $100 \mathrm{ml}$ in a volume flask. This extracts was used in specific analysis for the different mineral elements. Calcium and magnesium was determined by complexometric titration following the versanate EDTA titrimetric method (AOAC, 2000). Phosphorus in the test sample was determined by the molybdo vanadate colorimetric method (James, 1995). Iron was determined following the bathophenanthroline method of Lee and Stumm (1960) while sodium and potassium was determined by flame photometry. Triplicate digestion of each element and blanks were carried out on each element.

Preliminary qualitative screening of the phytochemical: The qualitative screening of the extract was carried out to determine the presence of secondary metabolites using the method described by Harborne (1998) and Parekh and Chanda (2007). Alkaloids were qualitatively detected by dragendroff reagent (potassium bismuth iodide), flavonoid by Benedict's solutions (Adamu et al., 1970), saponin by frothing test, tannin by wohler's test and phenol by ferric chloride solution as described by Ajuru et al. (2017).

Quantitative estimation of some phytochemicals: Phytate determination was carried out according to the procedure described by AOAC (1990), saponin was determined by the double solvent extraction gravimetric method described by Harborne (1973), phenol was determined by the Folin Ciocalteu reagent method (Mc Donald et al., 2001), alkaloid determination was carried out following the alkaline precipitation gravimetric method (Harborne, 1973), tannin was determined by Folin-Denis method (Polshettiwar et al., 2007) while flavonoid was determined by the procedure described by Harborne (1973).

Experimental design and statistical analysis: A simple factorial experiment was conducted in randomized complete block design (RCBD) where the three sampling location served as block, and the three different plant parts (leaves, root and bark) as treatments while the three stands of $P$. macrophylla from each location served as replicates. The data collected from this study was subjected to analysis of variance (ANOVA) using Statistical Package for Social Sciences (SPSS) v.16 and means were separated and compared to find the levels of significance of the plant parameters. Each of the measurements was carried out in triplicate and the results are expressed as Mean \pm SEM.

\section{RESULTS AND DISCUSSION}

Qualitative screening of phytochemicals: The results of the qualitative screening of the phytochemical in leaves, root, and bark of $P$. macrophylla is presented in Table 1. The result show that tannin, phenols, flavonoid, alkaloid, saponin and phytate were present in the leaves, root and bark of P. macrophylla. Compared to all other extracts, the root extract had the highest tannin, flavonoid, alkaloid, and saponin with high degree of precipitation (++, +++, +++, and +++), respectively while the leaves extract had the highest phenol and phytate with high degree of precipitation 
$(+++$ and +++$)$. This suggest that the roots and leaves of $P$. macrophylla are very promising in synthesizing these phytochemicals.

Table 1: Qualitative phytochemical analysis of leaves, root and bark of Pentaclethra macrophylla

\begin{tabular}{llll}
\hline Phytochemical & Leaves & Stem & Root \\
\hline Tannin & + & + & ++ \\
Phenol & +++ & + & ++ \\
Flavonoid & + & ++ & +++ \\
Alkaloid & + & ++ & +++ \\
Saponin & + & ++ & +++ \\
Phytate & +++ & + & ++ \\
\hline Key: + (present) $)$ & ++ (moderately present), and $+++($ adequately \\
present)
\end{tabular}

Quantitative screening of phytochemicals: The results of the quantitative phytochemical content in leaves, root and bark of $P$. macrophylla is summarized in Table 2. The result show that all the phytochemicals tested in this study were present in all the plant parts of Pentaclethra macrophylla. Consequently, the quantitative estimation of the percentage yield of chemical constituents of $P$. macrophylla were significantly raised, and significant differences was evidenced amongst the three plant parts (roots, leaves and bark). Among all the phytochemical constituents investigated in P. macrophylla, tannin $(1.42 \pm 0.00 \%)$, flavonoid $(3.75 \pm 0.35 \%)$, alkaloid $(1.30 \pm 0.14 \%)$, and saponin $(3.40 \pm 0.00 \%)$ had the highest content in root (Table 2) and these values were significantly $(\mathrm{P}<0.05)$ higher than their corresponding values in bark $(1.31 \pm 0.00,2.50 \pm 0.00,1.00 \pm 0.00$, and $2.40 \pm 0.14 \%)$ and leaves $(1.34 \pm 0.00,1.50 \pm 0.00,0.80 \pm 0.00$, and $8.25 \pm 0.28 \%$ ). The high presence of phytochemicals in root may be attributed to the inherent ability of the tree species ( $P$. macrophylla) to synthesize and store more of the phytochemicals (tannin, flavonoid, alkaloid, and saponin) in root than leaves and bark.

The high content of these phytochemicals in roots may be attributed to the ability of $P$. macrophylla roots to accumulate and store different phytochemicals in roots over time unlike the leaves that detached from the parent plant after a small or limited period of time (i.e. senescence). The value of flavonoid in this study increased from $1.50 \pm 0.00$ (leaves) to $3.75 \pm 0.35 \%$ (root), which is higher than $0.49 \pm 0.01$ to $0.74 \pm 0.01$ in Pterocaropus soyansii and Pterocarpus santalinoides leaves (Ndukwe and Ikpeama, 2013), 0.50 \pm 0.06 (seeds) to $1.50 \pm 0.13 \%$ (leaves) by Osabor et al. (2017) and $3.1 \%$ in Newbouldia laevis leaves (Yusuf et al., 2013) but lower than $11.24 \pm 0.15$ to $17.23 \pm 0.09$ $\%$ in Chrysophyllum albidium (Ibrahim et al., 2017) as well as 7.95, 10.49, 10.13, 10.48 and $13.91 \%$ in Albizzia lebbeck, Terminalia catappa, Terminalia mantaly, Citrus grandis and Khaya senegalensis (Tizhe et al., 2016). Flavonoid strengthen the blood capillaries and prevent the small cutaneous hemorrhage; it relieves cramps of the smooth muscles, improve circulations in the coronary arteries. Flavonoids are known for their anti-inflammatory and anti-allergic effect for inhibition of tumor production. In this study, the values of tannin ranged from $1.31 \pm 0.00$ (bark) to $1.42 \pm 0.00 \%$ (root), which is lower than $7.49 \pm 0.12$ to $10.19 \pm 0.12 \%$ recorded for Chrysophyllum albidium (Ibrahim et al., 2017) but higher than $0.23 \pm 0.01$ to $0.31 \pm 0.01$ in Pterocarpus soyansii and Pterocarpus santalinoides leaves, and $0.80 \pm 0.22$ to $1.20 \pm 0.32 \%$ reported by Osabor et al. (2017). Tannins compounds are widely distributed in many species of plants, where they play a role in protection from predation, as pesticides, and in plant growth regulation. Leaves that contain tannins are used for the treatment of intestinal disorders such as diarrhea and dysentery (Akindahunsi and Salawu, 2005) and healing of wounds (Ndukwe and Ikpeama, 2013). The highest significant $(\mathrm{P}<0.05)$ value for alkaloid was recorded in the roots $(1.30 \pm 0.14 \%$ and the value of alkaloid increased from $0.80 \pm 0.00$ (leaves) to $1.30 \pm 0.14 \%$ (root), which is well below $52.07 \%$ in N. laevis (Yusuf et al., 2013), 12.22 \pm 0.10 to $25.80 \pm 0.51 \%$ in C. albidium (Ibrahim et al., 2017) as well as 2.20, 3.20, 3.94 and $1.44 \%$ in Albizzia lebbeck, Terminalia catappa, Terminalia mantaly, and Khaya senegalensis (Tizhe et al., 2016) but higher than $0.4 \pm 0.11$ (leaves) to $0.52 \pm 0.68$ (seeds) by Osabor et al. (2017) and $0.41 \pm 0.01$ to $0.63 \pm 0.02$ in $P$. soyansii and $P$. santalinoides leaves (Ndukwe and Ikpeama, 2013). Alkaloid are nitrogen containing organic compounds and they (alkaloid) act as tranquilizers, pain reliever and against infectious micro-organism (Solomon and Craig, 1998). Alkaloids protect plants from herbivopous animals and should be harnessed for manufacturing of pesticides. In this study, the values of phytate increased from 8.25 \pm 0.28 (bark) to $11.20 \pm 0.00 \%$ (leaves), which is well above $0.42 \pm 0.10$ (seeds) to $0.60 \pm 0.32 \%$ reported by Osabor et al. (2017) and $0.34 \pm 0.01$ to $0.42 \pm 0.01$ in $P$. soyansii and $P$. santalinoides leaves (Ndukwe and Ikpeazu, 2013). Phytic acid may lower the incidence of colonic cancer and protect against other inflammatory bowel diseases. The value of saponin increased from $1.80 \pm 0.00$ (leaves) to $3.40 \pm 0.00 \%$ (roots), which is higher than $0.64 \%$ in N. laevis (Yusuf et al., 2013), $0.07 \pm 0.01$ to $0.41 \pm 0.02 \%$ in $C$. albidium (Ibrahim et al., 2017), $0.24 \pm 0.00$ to $0.35 \pm 0.01$ in $P$. soyansii and $P$. santalinoides leaves (Ndukwe and Ikpeama, 2013), $2.08 \%$ in D. edulis (Okwu and Nnamdi, 2008) and $0.30 \pm 0.42$ (seeds) to $0.50 \pm 0.22 \%$ (leaves) reported by Osabor et al. (2017). From the result, the values of phenol increased from $0.56 \pm 0.00$ (bark) to $4.47 \pm 0.13$ (leaves) which is well above $0.08 \pm 0.01$ to $0.15 \pm 0.01$ in Pterocarpus soyansii and Pterocarpus 
santalinoides leaves (Ndukwe and Ikpeama, 2013). Phenols protect plants from predators and pathogens by releasing odours and repelling substances that are detestable to animals including pests. According to Sofowora (1993), phenols are used to eliminate bacteria and to burn up parasites. Saponin also aid in absorption of nutrient and hormonal activity (Rahaman, 2010). The high content of phytochemicals in root of Pentaclethra macrophylla could have been the reason for its usage in treatment of ailment by the rural dwellers. Consequently, the roots of Pentaclethra macrophylla can be recommended for the manufacturing of drugs in pharmaceutical industries since it has high content of tannin, flavonoid, alkaloid, and saponin.

Table 2. Quantitative phytochemical content of the leaves, root and bark of Pentaclethra macrophylla

\begin{tabular}{lllllll}
\hline Sample & Tannin & Phenol & Flavonoid & Alkaloid & Saponin & Phytate \\
\hline Bark & $1.31^{\mathrm{c}} \pm 0.00$ & $0.56^{\mathrm{c}} \pm 0.00$ & $2.50^{\mathrm{b}} \pm 0.00$ & $1.00^{\mathrm{b}} \pm 0.00$ & $2.40^{\mathrm{b}} \pm 0.14$ & $8.25^{\mathrm{c}} \pm 0.28$ \\
Leaves & $1.34^{\mathrm{b}} \pm 0.00$ & $4.47^{\mathrm{a}} \pm 0.13$ & $1.50^{\mathrm{c}} \pm 0.00$ & $0.80^{\mathrm{c}} \pm 0.00$ & $1.80^{\mathrm{c}} \pm 0.00$ & $11.20^{\mathrm{a}} \pm 0.00$ \\
Root & $1.42^{\mathrm{a}} \pm 0.00$ & $2.65^{\mathrm{b}} \pm 0.00$ & $3.75^{\mathrm{a}} \pm 0.35$ & $1.30^{\mathrm{a}} \pm 0.14$ & $3.40^{\mathrm{a}} \pm 0.00$ & $9.28^{\mathrm{b}} \pm 0.18$ \\
\hline
\end{tabular}

Mean \pm standard deviation of triplicate determinations; Values on the same column with different superscripts are significantly different $(p<0.05)$.

Table 3: Mineral content of leaves, root and bark of Pentaclethra macrophylla $(\mathrm{mg} / 100 \mathrm{~g})$

\begin{tabular}{llllllc}
\hline Sample & \multicolumn{1}{c}{$\mathbf{M g}$} & $\mathbf{Z n}$ & $\mathbf{F e}$ & $\mathbf{N a}$ & $\mathbf{C a}$ & $\mathbf{P}$ \\
\hline Bark & $140.43^{\mathrm{b}} \pm 0.39$ & $3.05^{\mathrm{c}} \pm 0.00$ & $6.80^{\mathrm{c}} \pm 0.28$ & $124.49^{\mathrm{c}} \pm 0.00$ & $182.0^{30 \mathrm{~b}} \pm 0.00$ & $47.70^{\mathrm{a}} \pm 0.00$ \\
Leaves & $158.00^{\mathrm{a}} \pm 0.00$ & $4.60^{\mathrm{b}} \pm 0.00$ & $16.50^{\mathrm{a}} \pm 0.00$ & $165.00^{\mathrm{a}} \pm 0.00$ & $224.15^{\mathrm{a}} \pm 0.00$ & $32.20^{\mathrm{c}} \pm 0.28$ \\
Root & $128.50^{\mathrm{c}} \pm 0.00$ & $5.20^{\mathrm{a}} \pm 0.00$ & $12.80^{\mathrm{b}} \pm 0.00$ & $142.08^{\mathrm{b}} \pm 0.39$ & $168.42^{\mathrm{c}} \pm 0.00$ & $39.28^{\mathrm{b}} \pm 0.18$ \\
\hline
\end{tabular}

Mean \pm standard deviation of triplicate determinations; Values on the same column with different superscripts are significantly different $(p<0.05)$.

Essential Element Composition in leaves, root and bark of Pentaclethra macrophylla: The result of the mineral content in leaves, root and bark of Pentaclethra macrophylla is summarized in Table 3. The results show that the various plant parts of $P$. macrophylla contain the minerals tested in this study, and that the highest content of $\mathrm{Mg}(158.00 \pm 0.00$ $\mathrm{mg} / 100 \mathrm{~g}), \quad \mathrm{Fe} \quad(16.50 \pm 0.00 \mathrm{mg} / 100 \mathrm{~g}), \quad \mathrm{Na}$ $(165.00 \pm 0.00 \mathrm{mg} / 100 \mathrm{~g})$, and $\mathrm{Ca} \quad(224.15 \pm 0.00$ $\mathrm{mg} / 100 \mathrm{~g}$ ) were obtained in the leaves of $P$. macrophylla, which were significantly higher than their corresponding values in root $(128.50 \pm 0.00$, $12.80 \pm 0.00,142.08 \pm 0.39$ and $168.42 \pm 0.00 \mathrm{mg} / 100 \mathrm{~g})$ and bark $(140.43 \pm 0.39,6.80 \pm 0.28,124.49 \pm 0.00$ and $182.30 \pm 0.00 \mathrm{mg} / 100 \mathrm{~g})$. The high content of $\mathrm{Mg}, \mathrm{Fe}$, $\mathrm{Na}$ and $\mathrm{Ca}$ in leaves of $P$. macrophylla may be attributed to the availability of these elements in soil vis-à-vis the ability of the plant to take them up and translocate to the leaves. The highest significant value for $\mathrm{Zn}$ was recorded in the root $(5.20 \pm 0.00 \mathrm{mg} / 100 \mathrm{~g})$ while the highest significant value $(\mathrm{P}<0.05)$ for $\mathrm{P}$ is recorded in the bark $(47.70 \pm 0.00 \mathrm{mg} / 100 \mathrm{~g})$. Phosphorus is important for proper functioning of plants. The high content of $\mathrm{Zn}$ in roots may be attributed to the ability of the root to absorb and store $\mathrm{Zn}$ in the root than other parts of P. macrophylla. In order to resist the damaging effect of absorbing more than the allowable limit of trace metal in soil, plants adopt different strategies which include reducing the transfer of trace metal to the shoot or aerial parts and adsorbed it to the cell walls of the roots. The value of $\mathrm{Zn}(5.20 \pm 0.00 \mathrm{mg} / 100 \mathrm{~g})$ in this study is relatively lower than $6.56 \pm 0.10 \mathrm{mg} / 100 \mathrm{~g}$ of $\mathrm{Zn}$ reported by Onyeleke et al. (2014) and $9.78 \pm 0.61 \mathrm{mg} / 100 \mathrm{~g}$ of $\mathrm{Zn}$ reported by Enujiugha and Akanbi (2005) in $P$. macrophylla seeds. The highest significant value for $\mathrm{Mg}(158.00 \pm 0.00 \mathrm{mg} / 100 \mathrm{~g})$ was obtained in the leaves and it is higher than $126.14 \pm 0.04 \mathrm{mg} / 100 \mathrm{~g}$ reported in a similar study (Osabor et al., 2017), 3.62 $\mathrm{mg} / 100 \mathrm{~g}$ in Moringa oleifera leaves (Aye and Adegun, 2013) as well as 16.80, 95.86, 10.0, 13.60, 22.4 and $12.2 \mathrm{mg} / 100 \mathrm{~g}$ observed in Spondias mombin, Dennettia tripetala, Monodora myristica, Xylopia aethiopica, Gambeya albida, and Canarium schweinfurthii leaves (Dike, 2010), respectively. The high content of $\mathrm{Mg}$ in leaves may be attributed to its $(\mathrm{Mg})$ availability in soil and the ability of the plant $(P$. macrophylla) to take up $\mathrm{Mg}$ from the soil via the roots and transferred more to the fresh leaves than other parts for good growth and development. Magnesium act as an activator of various enzymes and the recommended daily allowance for women and men is 300-400 mg/day (NRC, 1974). The highest significant content of Fe was obtained in $P$. macrophylla leaves and the value $(16.50 \pm 0.00 \mathrm{mg} / 100 \mathrm{~g})$ is higher than $2.31 \mathrm{mg} / 100 \mathrm{~g}$ in Moringa oleifera leaves (Aye and Adegun, 2013) as well as $7.83 \mathrm{mg} / 100 \mathrm{~g}, 8.24 \mathrm{mg} / 100$ $\mathrm{g}, 8.40 \mathrm{mg} / 100 \mathrm{~g}$, and $4.10 \mathrm{mg} / 100 \mathrm{~g}$ in Spondias mombin, Xylopia aethiopica, Gambeya albida, and Canarium schweinfurthii leaves (Dike, 2010), respectively and $8.71 \pm 0.02$ of Fe recorded in seeds of $P$. macrophylla (Onyeleke et al., 2014) but lower than $55.28 \pm 0.11 \mathrm{mg} / 100 \mathrm{~g}$ in $P$. macrophylla leaves (Osabor et al., 2017). Plants reduce the transfer of trace metal such as Fe to the aerial part of plant (e.g. leaves) by compartmentation of the metal in the vacuole through the production of organic acids and formation of metal binding polypeptides known as 
phytochelatins (Hall, 2002). Iron is required for the formation of blood and its deficiency causes anemia (Turan et al., 2003). The highest significant $(\mathrm{P}<0.05)$ content of $\mathrm{Na}(165.00 \pm 0.00 \mathrm{mg} / 100 \mathrm{~g})$ was obtained in the leaves. The form of $\mathrm{Na}$ in soil (i.e. readily available for uptake) is implicated for the increased uptake of this nutrient in leaves. The value of $\mathrm{Na}$ in Pentaclethra macrophylla leaves $(165.00 \pm 0.00$ $\mathrm{mg} / 100 \mathrm{~g}$ ) is well above $4.56 \mathrm{mg} / 100 \mathrm{~g}$ in M. oleifera leaves as well as $11.32,12.46,11.92,9.57,42.00$, and 10.00 obtained in Spondias mombin, Dennettia tripetala, Monodora myristica, Xylopia aethiopica, Gambeya albida, and Canarium schweinfurthii leaves (Dike, 2010), respectively but lower than $265.68 \pm 0.72$ in a similar study (Osabor et al., 2017). Sodium is the principal electrolyte in extracellular fluids for the maintenance of normal osmotic pressure and water balance and the recommended dietary intake of sodium is $2500 \mathrm{mg} / \mathrm{day}$ for man (NRC, 1989). The highest significant $(\mathrm{P}<0.05)$ content of $\mathrm{Ca}$ $(224.15 \pm 0.00 \mathrm{mg} / 100 \mathrm{~g})$ was obtained in $P$. macrophylla leaves. The deep rooting system of $P$. macrophylla may have enhanced uptake, transfer and accumulation of $\mathrm{Ca}$ in an important organ such as leaf. The value of $\mathrm{Ca}(224.15 \pm 0.00 \mathrm{mg} / 100 \mathrm{~g})$ in this study is well above $16.03,8.45,28.72,42.75,21.10$, and $24.00 \mathrm{mg} / 100 \mathrm{~g}$ recorded for Spondias mombin, Dennettia tripetala, Monodora myristica, Xylopia aethiopica, Gambeya albida, and Canarium schweinfurthii leaves (Dike, 2010), respectively as well as $4.56 \mathrm{mg} / 100 \mathrm{~g}$ in M. oleifera leaves (Aye and Adegun, 2013) and $110.05 \pm 0.02 \mathrm{mg} / 100 \mathrm{~g}$ by Ogueke et al. (2010) for fermented P. macrophylla seeds. Calcium is an important mineral for normal growth of bones and teeth (Robinson, 1978) and the recommended daily calcium allowance for children and adult is 360-1200 mg/100 g (NRC, 1989). Generally, the therapeutic uses of Pentaclethra macrophylla leaves will supplement the level of minerals $(\mathrm{Mg}, \mathrm{Fe}, \mathrm{Na}$, and $\mathrm{Ca}$ ) in the body since most families in Nigeria relied heavily on starchy foods such as yam, gari, rice, potato among others that are low in minerals.

Conclusion: The result of the study show that the qualitative screening of the root extract of Pentaclethra macrophylla synthesized with high degree of precipitation tannin, flavonoid, alkaloid, and saponin. Quantitatively, the highest significant values of tannin, flavonoid, alkaloid, and saponin were recorded in the root while most of the minerals $(\mathrm{Mg}$, $\mathrm{Fe}, \mathrm{Na}$, and $\mathrm{Ca}$ ) tested in this study occurred in the leaves. This suggest that $P$. macrophylla is a promising tree species with good medicinal and nutrition properties that can improve human health.

\section{REFERENCES}

Adamu, J; Jhonson, R; Nilcox, CF (1970). Laboratory experiments, inorganic chemistry. The Meamillian Company, London, UK.

Ajuru, MG; Williams, LF; Ajuru, G (2017). Qualitative and quantitative phytochemical screening of some plants used in ethnomedicine in the Niger Delta Region of Nigeria. J. Food Nutr. Sci. 5(5): 198-205.

Akindahunsi, AA; Salawu, SO (2005). Phytochemical screening of nutrient and antinutrient composition of selected tropical green leafy vegetables. Afr. J. Biotech. 4: 497 - 501.

Alinnor, IJ; Oze, R (2011). Chemical evaluation of the nutritive value of Pentaclethra macrophylla Benth. (African Oil Bean) Seeds. Pakistan J. Nutr. 10(4): 355-359.

AOAC (2000). Association of Official Analytical Chemists International Arlington, Virginia.

AOAC 1990. Official Methods of Analysis. Association of Official Analytical Chemist, Arlington, VA., USA.

Asl, MN; Hossein, H (2008). Review of pharmacological effects of Glycyrrhiza sp. and its bioactive compounds. Phyt. Res. 22(6): 709-724.

Aye, PA; Adegun, MK (2013). Chemical composition and some functional properties of Moringa, Leucaena, and Gliricidia leaf meals. Agric. Biol. J. N. Am. 4(1): 71-77.

Dike, MC (2010). Proximate, phytochemical and nutrient compositions of some fruits, seeds and leaves of some plant species at Umudike, Nigeria. J. Agric. Biol. Sci. 5(1): 7-16.

Enujiugha, VN; Akanbi, CT (2005). Compositional changes in African oil bean (Pentaclethra macrophylla Benth) seeds during thermal processing. Pak. J. Nutr. 4(1): 27-31.

Hall, JL (2002). Cellular mechanisms for heavy metal detoxification and tolerance. J. Exp. Bot. 53: 1 - 11 .

Harbone, JB (1973). Phytochemical methods. A guide to modern techniques of plant analysis. London, UK, Chapman and Hall.

Harborne, JB (1998). Phytochemical Methods: A Guide to Modern Techniques of Plant Analysis. Chapman and Hall, London, UK.

Ibrahim, HO; Osilesi, O; Adebawo, OO; Onajobi, FD; Karigidi, KO; Muhammad, LB (2017). nutrients compositions and phytochemical contents of edible 
parts of Chrysophyllum albidum fruit. J. Nutr. Food Sci. 7(2): 1-9.

James, CS (1995). Analytical chemistry of food. SealeHayne Faculty of Agriculture, Food and Land use, Department of Agric. and Food studies, Univ. of Polymouth, UK.

Keay, RWJ (1959). An outlines of Nigeria vegetation. Government Printer, Lagos.

Lee, GF; Stumm, W (960). Determination of ferrous iron in the presence of ferric iron with bathophenanthroline. J. AWWA 52: 1567 - 1574.

McDonald, S; Prenzler, PD; Antolovich, M; Robards, K (2001). Phenolic content and antioxidant activity of olive extracts. Food Chem. 73: 73 - 84.

Ndukwe, OK; Ikpeama, A (2013). Comparative evaluation of the phytochemical and proximate constituents of Oha (Pterocarpus soyansii) and nturukpa (Pterocarpus santalinoides) leaves. Int. J. Acad. Res. Prog. Edu. Dev. 2(3): 22-31.

NRC (1974). National Research Council recommended daily allowances. United States Nutrition and Medicinal Board, National Academy of Science, Washington DC.

NRC (1989). National Research Council recommended dietary allowance. United States Nutrition and Medicinal Board, National Academic Press, Washington DC.

Ogueke, CC; Nwosu, JN; Owuamanam, CI; Iwouno, JN (2010). Ugba, the fermented African oilbean seeds; its production, chemical composition, preservation, safety and health benefits. Pak. J. Biol. Sci. 13: 489 - 496.

Okwu, DE; Nnamdi, FU (2008). Evaluation of the chemical composition of Dacryodes edulis sp. check for this species in other resources and Raphia hookeri Mann and wendl exudates used in herbal medicine in South Eastern Nigeria. Afr. J. Trad. Compl. Altern. Med. 5: 194 - 200.

Onyeleke, GO; Odedeji, JO; Ishola, AD; Afolabi, O (2014). Phytochemical screening and nutritional evaluation of African oil bean (Pentaclethra macrophylla) seeds. J. Environ. Sci. Toxicol. Food Technol. 8(2): 14-17.
Osabor, VN; Okonkwo, PC; Ikeuba, AI (2017). Chemical profile of leaves and seeds of Pentaclethra macrophylla Benth. J Med. Plant Herb. Therap. Res. 5: $11-17$.

Parekh, J; Chanda, S (2007). Antibacterial and phytochemical studies on twelve species of Indian medicinal plants. Afr. J. Biomed. Res. 10: 175 - 181.

Polshettiwar, SA; Ganjiwale, RO (2007). Spectrophotometric estimation of total tannins in some ayurvedic eye drops. Ind. J. Pharm. Sci. 69(4): 574-576.

Rahaman, O (2010). Phytochemical screening test and medicinal values of plants active properties. Mahesh Jain.

Robinson, CH (1978). Mineral elements. In: (ed). Fundamentals of normal nutrition. McMilian Publication Company Incorporated, New York, p.

Sofowora, A (1993). Medicinal plants and traditional medicine in Africa. Spectrum Books Ltd. Ibadan, Nigeria.

Solomon, G; Craig, F (1998). Organic chemistry. John Wiley and sons Inc., NY.

Tizhe, TD; Alonge, SO; Dakare, M (2016). Comparative study of the quantitative phytochemical constituents and antibacterial activity of five tree species. Eur. J. Adv. Res. Biol. Life Sci. 4(1): 29-37.

Turan, M; Kordis, S; Zeyin, A; Dursau, A; Sezen, Y (2003). Macro and micro mineral content of some wild edible leaves consumed in Eastern Anatola communications in school. Soc. Plants Anal. 23: 129 -130 .

UNESCO (1996). Culture and Health, Orientation textsWorld Decade for Cultural development Documents CLT/DEC, Paris, France.

You, J; Wang, X; Yan, Y; Jin, F; Huang, B (1993). Effects of active constituents of Chinese herbal medicine on HMG-CA Reductase. Chem. Abstr. 120(7): 70 .

Yusuf, AO; Sowande, OS; Sogunle OM; Akinbami, VA; Oyebanji, OO; Yusuf, OA; Ekunseitan, DA; Adeleye, KA and Aina, ABJ (2013). Accessing the nutritional composition and phytochemical screening of Panicum maximum and Newbouldia laevis leaves. Nig. J. Ani. Prod. 161 - 167. 